\title{
Childhood Traumas and Impulsivity: The Mediating Role of Parental Attitudes
}

\author{
DOI: $10.26466 /$ opus.904996
}

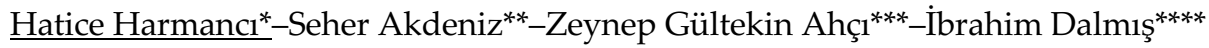

* Dr. Öğr. Üyesi, KTO Karatay Üniversitesi, Sosyal ve Beşeri Bilimler Fakültesi, Konya/Türkiye E-Posta: hatice.harmanci@karatay.edu.tr ORCID: 0000-0003-4064-5391

** Dr. Öğr. Üyesi, KTO Karatay Üniversitesi, Sosyal ve Beşeri Bilimler Fakültesi, Konya/Türkiye E-Posta: seher.akdeniz@karatay.edu.tr

ORCID: $\quad$ 0000-0002-2282-9165

*** Dr. Öğr. Üyesi, KTO Karatay Üniversitesi, Sosyal ve Beşeri Bilimler Fakültesi, Konya/Türkiye

E-Posta: zeynep.ahci@karatay.edu.tr ORCID: $\quad$ 0000-0002-2383-7167

**** Dr. Öğr. Üyesi, KTO Karatay Üniversitesi, Sosyal ve Beşeri Bilimler Fakültesi, Konya/Türkiye

E-Posta: ibrahim.dalmis@yahoo.com, ORCID: $\quad$ 0000-0001-9558-5619

\begin{abstract}
Childhood traumas (CT) are common and an important risk factor for the development of mental complaints and psychopathologies. The first aim of the research was to determine the frequency of CT in a non-clinical sample and to investigate the relationship between this and impulsivity. Our second aim was to examine the mediating role of parental attitudes in people with impulsivity. The research group consists of 276 university students who met the inclusion criteria. Sociodemographic information form, Childhood Trauma Scale, Child Rearing Attitude Scale and Barrate Impulsivity Scale Short Form were applied to the participants who were interviewed face to face. SPSS 22.0 and LISREL 8.8 were used for the data analysis. The prevalence of CT was $30.9 \%$ in the research group. The most common CT subtype is emotional abuse and emotional neglect. The relationship between $\mathrm{CT}$ and impulsivity has been found, and parental attitudes are the key factors in the development of impulsivity. References from the parents are very important in understanding and making sense of the trauma experienced by the child. Parent education on this subject is very important for the prevention of psychopathologies that will develop due to trauma.
\end{abstract}

Keywords: Childhood traumas, abuse, neglect, impulsivity, parental attitudes. 


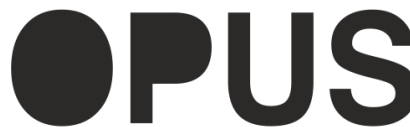

Uluslararası Toplum Araştırmaları Dergisi International Journal of Society Researches
E-ISSN : 2528-9535

YIl Year: 11

Cilt Volume: 18

Sayı Issue :Eğitim Bilimleri Özel Sayısı

Eylül September 2021

Makalenin Gelis Tarihi Received Date: 29/03/2021

Makalenin Kabul Tarihi Accepted Date: 03/06/2021

\section{Çocukluk Çağı Travmaları ve Dürtüsellik: Ebeveyn Tutumlarının Aracı Rolü}

Öz

Çocukluk çağı travmaları (ÇÇT) toplumlarda sıkça görülen ve ruhsal şikayetler ya da ruhsal bozuklukların gelişimine sebep olabilecek risk faktörlerindendir. Araştırmamızın ilk amacı klinik olmayan bir örneklemde ÇÇT sıklğ̆ını saptamak ve bu durumun dürtüsellikle olan ilişkisini araştırmaktır. İkinci amacımız ise dürtüsellik gelişen kişilerde ebeveyn tutumlarının aracılık rolünü incelemektir. Araştırma grubunu çalı̧̧maya katılmaya gönüllü olan, çalışmaya dahil edilme kriterlerine uygun 276 üniversite öğrencisi oluşturmaktadır. Yüz yüze görüşme yapılan katılımcılara sosyodemografik bilgi formu, Çocukluk Çağı Travmaları Ölçeği, Çocuk Yetiştirme Tutumları Ölçeği ve Barrat Dürtüsellik Ölçeği Kısa Formu ölçekleri uygulanmıştır. Verilerin analizinde SPSS 22.0 ve LISREL 8.8 istatistik programları kullanılmıştır. Araştırma grubunda ÇÇT yaygınlığı \%30,9 bulunmuştur. En sık ÇÇT alt tipi duygusal istismar ve duygusal ihmaldir. Çocukluk çağı travmalarl, dürtüselliğin gelişmesinde etkili bir faktördür ve ÇÇT öyküsü olan kişilerde dürtüselliğin gelişmesinde ebeveyn tutumları aracı rol oynamaktadır. Çocuğun yaşadığı travmayı anlaması ve anlamlandırmasında ebeveynlerinden aldığı referanslar oldukça önemlidir. Bu konuda yapılacak ebeveyn eğitimleri, travmaya bağhl gelişecek psikopatolojilerin önlenmesi açısından oldukça önemlidir.

Anahtar Kelimeler: Çocukluk çă̆ı travmaları, istismar, ihmal, dürtüsellik, ebeveyn tutumları. 


\section{Introduction}

Childhood traumas (CT) are defined as individuals before the age of 18 years experiencing physical, mental, and sexual neglect or abuse or experiencing negativities such as parental separation, death, accident, and natural disaster (Aktas, 2019, p.14). Exposure to trauma at a young age affects the development of the individual and increases the risk of developing psychopathologies; hence, it is considered as an important issue. CT are a public health problem that is common worldwide but it is less detected owing to sociocultural reasons. The Social Services and Child Protection Agency together with United Nations International Children's Emergency Fund (UNICEF) published Child Abuse and Domestic Violence in Turkey in 2010. In Turkey, according to survey results, $51 \%$ of children between the age of 7 and 18 years were found to be exposed to emotional and physical abuse, $43 \%$ physical neglect, 25\% emotional neglect, and 3\% sexual abuse. In the same study, $56 \%$ of children witnessed physical abuse, $49 \%$ emotional abuse, and 10\% sexual abuse (Social Services and Child Protection Agency-UNICEF, 2010, p.17-37). The prevalence of physical abuse in an international survey was between $4 \%$ to $85 \%$ in the United States and Chile, $21 \%$ to $82 \%$ in the Philippines, $36 \%$ to $70 \%$ in India, and $26 \%$ to $72 \%$ in Egypt (Runyan, May-Chahal and Hassan, 2002). In another study that involved 4 countries, the frequency of emotional abuse in children was $66 \%$, the frequency of physical abuse was $55 \%$, and the frequency of sexual abuse was 18\% (Zolotor et al., 2009, p.839).

Every traumatic experience harms the child's perception of safety and belief in a fair world. This can lead to impairment in the child's emotional regulation, decreased self-esteem (Dereboy, Demirkapi, Sakiroglu and Ozturk, 2018) or difficulty in forgiving self and other for what he or she experienced or influence his or her sense of identity (Guloglu, Karairmak and Emiral, 2016). Behavioral patterns, such as reproducing and re-experiencing similar trauma, can be observed in children who have difficulty in making sense of the trauma they experienced (Herman, 1992, p.38). The mental effects that will develop in the short and long term after trauma change according to the child's perception and interpretation (Aktas, 2019, p.13). Depending on the their developmental level, children determine their emotions, and behaviors by taking their parents as reference. It is 
reported that individuals who are protected and receive close support from their families are able to be cope with trauma more easily (Golge, 2005, p.22).

Individuals who are exposed to repeated traumas and who do not get effective support after trauma may also experience more mental problems in adulthood. Psychopathologies such as depression (Thai et al., 2020, p.6), bipolar disorder, dissociative disorders (Yilmaz et al., 2016, p.188) and alcohol substance addiction (Roy, 2005, p.148) are more frequently observed in these individuals, along with problems such as difficulties in social relations, use of unhealthy coping methods, impulsivity, and anger control problems (Sen, 2019, p.89). It is also reported that developed psychopathologies are more resistant to treatment and the risk of suicide attempts is higher durconsing treatment (Yagci, Avci, Tasdelen and Kivrak, 2018, p.554).

Impulsivity is a pattern of thought or behavior performed without thinking about the action and concidering the results, which can often result end up negatively. It is not a pathology in itself, but it has been reported as the cause of many social problems and psychopathologies (Moeller, Barrat, Dougherty, Schmitz and Swann, 2001). In the literature, there are studies reporting that impulsivity may develop depending on the age, duration, and severity of trauma (Braquehais, Oquendo, BacaGarcia and Sher, 2010; Narvaez et al., 2012, p.240) but there was no research describing the factors that mediate the development of impulsivity.

Childhood traumas and related psychopathologies are investigated from different aspects because of its large mass effect. In people with a history of trauma, developing a model explaining the factors that mediate the development and course of more resistant mental problems is very important for the proactive approach. This study aims to determine the frequency of CT in a nonclinical sample and to investigate the relationship between trauma experience and impulsivity and, if experiencing trauma is associated with the development of impulsivity, to examine the mediating role of parental attitudes in developing impulsivity. 


\section{Method}

This research is a descriptive study in the relational screening model. The study group consists of university students studying during the 20192020 academic years. Volunteering was based on study participation. Inclusion criteria for the study were as follows: (1) being over the age of 18 years, (2) no active psychiatric or physical illness, (3) no previous history of psychiatric or physical illness, and (4) being raised by their parents. The research was conducted in a nonclinical sample group to prevent the variables in the study from being affected by another mental or physical disease or drug use. In the first stage, data were collected from 332 university students, who were reached by convenience sampling method, that is, face-to-face application method. Data of 56 students who do not meet the inclusion criteria were not used. Scales applied to the participants were a sociodemographic information form created by the researchers, Childhood Trauma Scale, Child Rearing Attitudes Scale, and Barratt Impulsiveness Scale Short Form. Permission was obtained from the local ethics committee for this study. The research protocol was studied in accordance with the Declaration of Helsinki.

Sociodemographic information form: The form was prepared by the researchers. It contains open-ended questions regarding the gender, age, education year, marital status, general health status, and family history of the participants.

Childhood Trauma Scale: The scale was developed by Bernstein et al. to detect childhood mental traumas (Bernstein et al., 1994, s. 1132). The Likert-type scale is based on self-report and consists of 28 items. It has 5 subdimensions: physical neglect and physical abuse, emotional neglect and emotional abuse, and sexual abuse. The Turkish validity and reliability study of the scale was conducted by Sar et al. (Sar, Ozturk and Ikikardes, 2012). In the study, internal consistency was found high, the Cronbach's alpha value was 0.93 and Guttman split-half test coefficient was 0.97 . The result of structural validity and internal consistency analysis made it possible to evaluate the scale as a valid and reliable data collection tool. 
Child Rearing Attitudes Scale: The scale was developed by Steinberg et al. to assess the way of raising children perceived from the individual's relationships with their parents (Steinberg, Lamborn, Darling, Mounts and Dornbusch, 1994). The Likert-type scale consists of 22 items and the participant responds by describing his or her relationship with his or her parents. The scale consists of 4 sub dimensions, namely, involvement (acceptance-love) and strict supervision, separately for the mother and father. The Turkish validity and reliability study of the scale was performed by Sumer and Gungor (1999). In the study, the Cronbach's alpha values waried between 0.70 and 0.94 for sub-dimensions. The result of structural validity and internal consistency analysis made it possible to evaluate the scale as a valid and reliable data collection tool.

Barratt Impulsiveness Scale Short Form: The scale originally developed to measure the impulsivity level of individuals was revised by Patton et al. (Patton, Stanford and Barrat,1995). The Likert-type scale is based on self-report and consists of 30 items. The scale consists of the following 3 sub dimensions: not being able to plan, motor impulsivity, and attention impulsivity. The Turkish validity and reliability study of the scale was conducted by Tamam et al. (2013). In the study, the scale was found to have enough reliability. The Cronbach's alpha values varied between 0.64 and 0.82 . The result of structural validity and internal consistency analysis made it possible to evaluate the scale as a valid and reliable data collection tool.

Statistical analysis: SPSS 22.0 and LISREL 8.8 were used for the data analysis. SPSS 22.0 was used for descriptive statistics and normality analyses. The data met the normal distribution criteria. LISREL 8.8 is used to test the measurement model and structural equation model. Two model tests were performed within the structural equation model. The fit indices for the confirmatory measurement model are based on root mean square error of approximation (RMSEA), root mean square residual (RMR), normed fit index (NFI), comparative fit index (CFI), and goodness of fit index (GFI). It was reviewed. 


\section{Results}

After the exclusion of the 56 participants analysis were conducted on 211 women $(76,7 \%)$ and 65 men $(23,6 \%)$. The average age of the participants is $19.68 \pm 2.09$ years.

The prevalence of CT was $30.9 \%$ in the study group. In terms of subtypes of trauma, the most common was emotional abuse $(27.3 \%)$, and emotional neglect $(12.7 \%)$, physical neglect $(10.9 \%)$, physical abuse $(8.7 \%)$, and sexual abuse $(8.4 \%)$ followed respectively. Some individuals have more than 1 subtype $(16,7 \%)$. Gender differences for CT total and subscale scores were determined by independent samples $t$-test. The results of the analysis indicated that the total trauma $(\mathrm{t} 270=-2.079 ; P<0.05)$ and physical neglect scores (t270 $=-3.005 ; P<0.05)$ between the female and male participants differed significantly. Accordingly, males' total trauma $(\bar{X}=$ $32,459$; ss $=5761)$ and physical neglect $(\bar{X}=6,262$; ss $=1526)$ scores were higher than women's total trauma $(\bar{X}=30,867$; ss $=5115)$ and physical neglect $(\bar{X}=5,715$; ss $=1161)$ scores.

Three different models regarding the research questions have been tested. Confirmatory measurement model was applied to determine the coefficients of fit between variables, and the findings are presented in Figure 1.

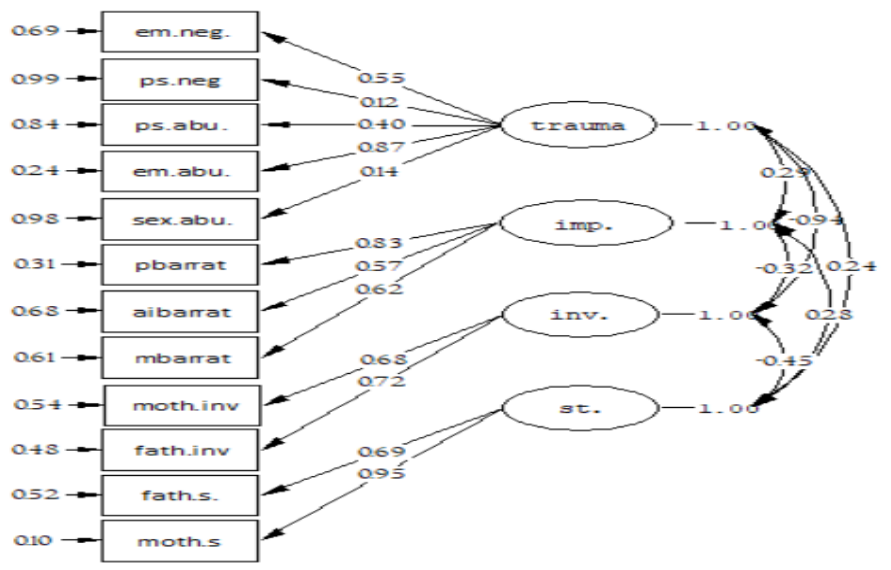

Figure 1. Measurement model 
em.neg. = emotional neglect; ps.neg. $=$ psysical neglect; ps.abu $=$ psysical abuse; $\mathrm{em} . \mathrm{abu}=$ emotional abuse; sex.abu. $=$ sexual abuse; pbarrat $=$ not being able to plan (Barrat scale-sub dimension); aibarrat = attention impulsivity (Barrat scale-sub dimension); mbarrat = motor impulsivity (Barrat scale-sub dimension); moth.inv = mother involvement (acceptancelove); fath.inv = father involvement (acceptance-love); fath.s. = father strict supervision; moth.s. = mother strict supervision; imp. = impulsivity; inv. = involvement (acceptance-love); st. = strict supervision

Fit indices for the confirmatory measurement model were good (x2/df $=1.89, \mathrm{RMSEA}=.057, \mathrm{RMR}=.053, \mathrm{NFI}=.91, \mathrm{CFI}=.96, \mathrm{GFI}=.95)$ (Figure 1 ). The good-fitting measurement model indicated that there were significant and harmonious relationships between the variables that make up the model.

Within the scope of the research, the direct and indirect effects of CTs on impulsivity were examined using structural equation models. In model 1 , the direct predictive effect of CTs on impulsivity was tested. The result of the structural equation analysis regarding the direct relationships between the variables is presented in Figure 2.

CTs had a positive and significant predictive coefficient on impulsivity $(\beta=.36, P<0.05)$ and corresponding fit indices were sufficient $(\mathrm{x} 2 / \mathrm{df}=$ $1.57, \mathrm{RMSEA}=.045, \mathrm{RMR}=.041, \mathrm{NFI}=.92, \mathrm{CFI}=.96, \mathrm{GFI}=.97)$ (Figure 2). em.abu = emotional abuse; ps.abu = psysical abuse; ps.neg. $=$ psysical neglect; em.neg. = emotional neglect; sex.abu. = sexual abuse; imp. = impulsivity; pbarrat = not being able to plan (Barrat scale-sub dimension); aibarrat $=$ attention impulsivity (Barrat scale-sub dimension); mbarrat = motor impulsivity (Barrat scale-sub dimension) 


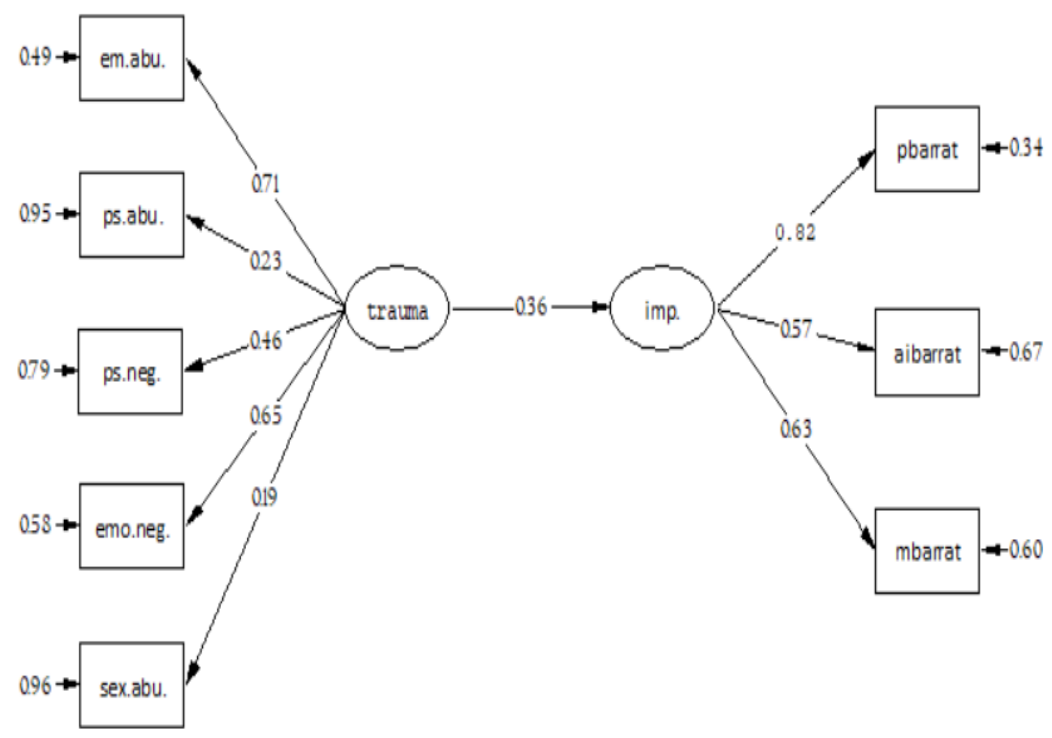

Figure 2. Structural Equation Model analysis findings related to Model 1

Parental interest and parental strict control variables mediated the relationship between CTs and impulsivity (Figure 3). The model in question is a full mediation model and the partial mediation model was tested beforehand. In this context, when the intermediary variables were added to the model, first, the model was tested without removing the path from CTs to impulsivity from the model. It was determined that the model did not fit well, then the path was removed from the model and the full intermediary model was tested. In the full mediation model, it was found that CTs predicted the parental interest variable $(\beta=-.99, P<0.05)$ and parental strict control variable $(\beta=.36, P<0.05)$. Likewise, parental interest variable has a predictive effect on impulsivity $(\beta=-.24, P<0.05)$ and parental strict control variable on impulsivity $(\beta=.20, P<0.05)$. When the fit indices of the model in question were examined, it was found that the intermediary model had a good fit $(x 2 / \mathrm{df}=2.03, \mathrm{RMSEA}=.061, \mathrm{RMR}=.053, \mathrm{NFI}=$ $.90, \mathrm{CFI}=.95, \mathrm{GFI}=.94)$. As a result, it can be seen that $\mathrm{CT}$ s have an indirect and strong effect on impulsivity through parental interest and parental strict control variables. 


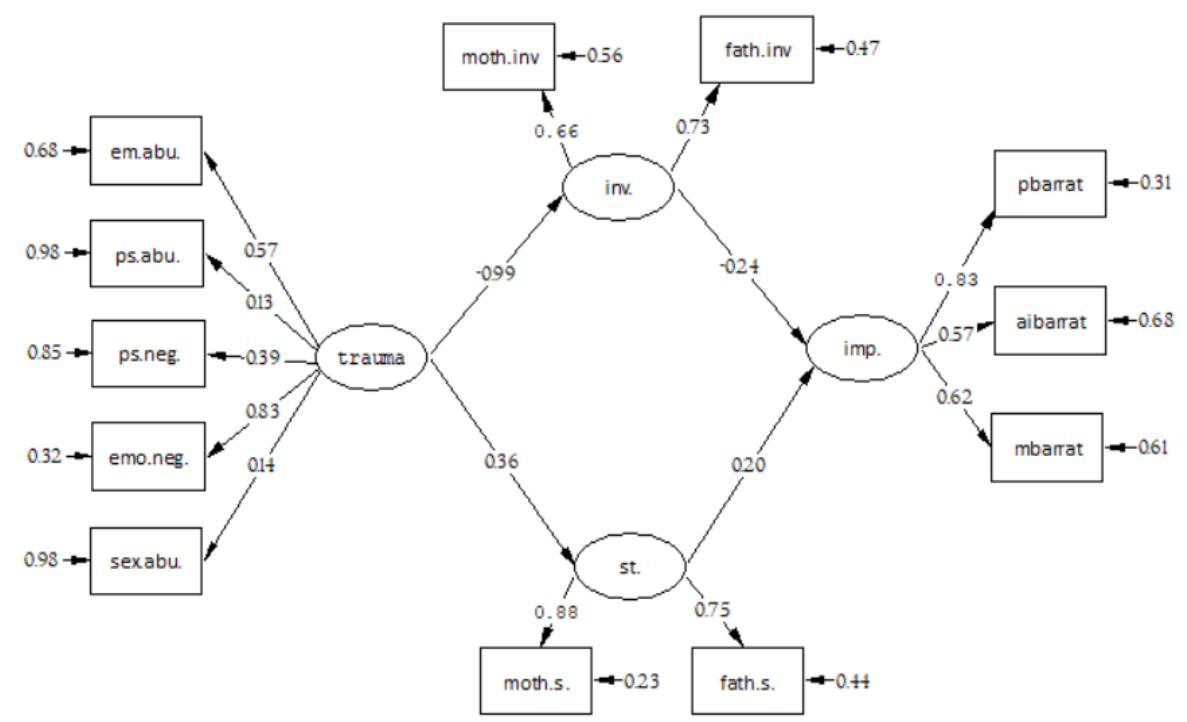

Figure 3. Structural Equation Model analysis findings related to Model 2

em.abu $=$ emotional abuse; ps.abu = psysical abuse; ps.neg. $=$ psysical neglect; emo.neg. $=$ emotional neglect; sex.abu. $=$ sexual abuse; inv. $=$ involvement (acceptance-love); moth.inv = mother involvement (acceptance-love); fath.inv = father involvement ( acceptance-love); st. = strict supervision; moth.s. = mother strict supervision; fath.s. $=$ father strict supervision; imp. = impulsivity; pbarrat $=$ not being able to plan (Barrat scalesub dimension); aibarrat = attention impulsivity (Barrat scale-sub dimension); mbarrat $=$ motor impulsivity (Barrat scale-sub dimension)

\section{Discussion and Conclusion}

In the study the prevalence of CT was $30.9 \%$. The most common types of trauma were emotional abuse (27.3\%) and emotional neglect $(12.7 \%)$. Total CT and physical neglect in men were significantly higher than in women. In the literature, CT prevalence was reported to reach up to $82 \%$ (Runyan et al., 2002, p.62). In her research with university students, Yoyen found the prevalence of CT to be $31.1 \%$. In the same study, the existence of physical neglect and emotional abuse was emphasized, and it was also 
reported that physical neglect was more frequent in men (Yoyen, 2017, 270-275). In their research using clinical and nonclinical sampling, Karos et al. (2014) reported that emotional neglect and abuse were the most common type of trauma (Karos, Niederstrasser, Abidi, Bernstein and Bader, 2014). There are varying results in the literature regarding the relationship between gender and CT. For instance one study reported that in early years of life all types of trauma were more frequent in males (Guloglu et al., 2016, p.313). In another study only the sexual abuse rate was found to be higher in males (Pereda, Guilera, Forns and Gomez-Benito, 1994). Yet another study findings revealed similar prevelances for both genders (Children's Bureau, 2016). As a result, it can be said that our findings are partially compatible with the literature.

In our study, it was tested whether parental attitudes play a mediating role between CT and impulsivity. When model 1 was examined, it was seen that CTs had a direct predictive effect on impulsivity $(\beta=.36, P<$ $0.05)$. In the literature, there are studies reporting that individuals who experienced CT had impulsivity and coexistent psychopathologies (Corstorphine, Waller, Lawson and Ganis, 2007; Cuomo, Sarchiapone, Di Giannantonio, Mancini and Roy, 2008). In a study on war veterans, Ruggiero et al. (1999) revealed that there was a significant relationship between impulsivity and CT. Brodsky et al. also stated that individuals with childhood physical or sexual abuse were more impulsive and more likely to attempt suicide (Brodsky et al., 2001, p.1871). The results of the study suggests that childhood abuse may be an environmental risk factor for the development of impulsivity.

When the findings of model 2 were analyzed, it was found that there was a negative relationship between $\mathrm{CT}$ and the parental involvement variable and a positive relationship between $\mathrm{CT}$ and the parental strict control variable. According to the literature, children, especially at an early age, are often traumatized in their own environment and by those they live with (Sofuoglu et al., 2014, p.47). A study reported that in $77 \%$ of the cases, abuser was a family member (Kara, Bicer and Gokalp, 2004). Yet, in order to prevent childhood trauma and to support healing after the exposure to trauma, family involvement and acceptance is very important. While perceived acceptance from the mother and father significantly increases the child's general psychological adjustment (Erkman and Rohner, 
2006, p.251), strict parenting has been shown to reduce the child's mental resilience (Miller-Graff, Scheid, Guzmán and Grein, 2020). According to the research of Fitzgerald and Gallus (2020), emotional support from the family reduces the development of depression in people with CT. In a research by Morrow et al. (2012), support from close environment, good relationships, and spiritual belief were found to be effective in overcoming trauma. It has also been notified that inconsistent and unsupportive parental behaviours were related with emotion dysregulation in children and identity problems in adolescents (Dereboy et al., 2018, p.269; Sekaran et al., 2020, p.2). Failures to recognize feelings of self and others, and to exhibit appropriate and consistent personality traits may cause deterioration in interpersonal relationships and result in more trauma exposure in return (Braquehais et al., 2010, p.121). Parents' authoritarian and oppressive attitudes can lead to lower self-esteem, more intense learned helplessness (Erdogdu, 2006, p.98) or inconsistent behaviours in children (Herman, 1992, p.35). Correspondingly, the study results revealed that parental attitude predicted whether a child would experience a trauma and how a trauma would affect a child.

To the extent of our knowledge, there are no studies that examine factors which mediate the emergence of impulsivity in the relationship between CT and impulsivity. One interesting finding of the study is the fullmediation role of parental attitudes in the relationship between CT and impulsivity. It was found that the development of impulsivity decreased $(\beta=-.24)$ when the parent was involved and accepting, and the impulsivity increased when the parent was more authoritative and suppressive $(\beta=$ .20). Since there are age related changes in children's evaluations of trauma experiences, their reactions to trauma also vary. They learn how to make sense of events and to react them throug social referencing at an early age. They imitate their parents' emotions and behaviours. Parental attitude in the face of negativity, his or her involvement and acceptance toward the child will lessen trauma's impact on child (Gewirtz, Forgatch and Wieling, 2008). Parental neglect may put children at a greater risk for wide variety of early stress factors or increase the negative effect of abuse on mental health (Jaffee and Price, 2007, p.432). On the contrary, the risks of traumatic experiences at an early age can be reduced in the context of a positive family or social environment. Children with trauma are known to 
be exposed to negativities caused by emotional imbalance, impulsivity, and behavior control problems more often, and the risk of mental disorders increases as the number of exposures increases (Shipman et al., 2007, p.268). All in all, the literature supports present study findings regarding the role of parental attitudes.

There are some limitations of our research. Firstly, it is cross-sectional study which makes it impossible to draw causal inferences. In the future, model should be tested on longitudinal data. Secondly, self-report scales were administered in order to assess $\mathrm{CT}$, parental attitudes and impulsivity. Data gathered from multiple sources of information would increase the quality and accuracy of the data. Another important point is that the study was conducted on a non-clinical sample. However, in the future a comparison of clinical and non-clinical sample may reveal important features of the relationship between impulsivity and $\mathrm{CT}$ and the mediational role of parental attitudes.

In conclusion, $\mathrm{CT}$ is a situation encountered in every society, which can cause many psychological, physical, and economic disadvantages in terms of its results. It is quite difficult to prevent trauma completely, but its effects can be minimized by evidence-based interventions. In terms of proactive approach, raising the awareness of parents on the issue and training programs would be an important step in protecting children's mental health. Psychiatrically, (1) early and effective intervention in CTs will significantly change the prognosis of mental disorders, and (2) CT should be kept in mind in the etiology of resistant psychopathologies encountered in adulthood and the treatment plan should be prepared accordingly. Again, there is a need for studies on this subject that have wider participation and accompany different regions. The investigation of factors other than parental attitudes in the development of impulsivity as a result of CT will also enrich the literature.

\section{References}

Aktas, F. (2019). The relationshitp between childhood traumas, emotional schemas and cognitive emotion regulation strategies in males with a history of substance abuse: A controlled study. (Unpublished master's thesis). Isık University Social Sciences Institute, Istanbul. 
Bernstein, D.P., Fink, L., Handelsman, L., Foote, J., Lovejoy, M., Wenzel, K. and Ruggiero, J. (1994). Initial reliability and validity of a new retrospective measure of child abuse and neglect. Am J Psychiatry, 151, 1132-1136.

Braquehais, M.D., Oquendo, M.A., Baca-Garcia, E. and Sher, L. (2010). Is impulsivity a link between childhood abuse and suicide? Compr Psychiatry, 51, 121-129.

Brodsky, B.S., Oquendo, M., Ellis, S.P., Haas, G.L., Malone, K.M. and Mann, J.J. (2001). The relationship of childhood abuse to impulsivity and suicidal behavior in adults with majör depression. Am J Psychiatry, 158, 1871-1877.

Children's Bureau. Child maltreatment US. 2016. Department of health and human service, administration for children and families, administration on children, youth and families.

https://www.acf.hhs.gov/sites/default/files/cb/cm2016.pdf. Data of access, 30 September 2020

Corstorphine, E., Waller, G., Lawson, R. and Ganis, C. (2007). Trauma and multiimpulsivity in the eating disorders. Eat Behav, 8, 23-30.

Cuomo, C., Sarchiapone, M., Di Giannantonio, M., Mancini, M. and Roy, A. (2008). Agression, impulsivity, personality traits, and childhood trauma of prisoners with substance abuse and addiction. Am J Drug Alcohol Abuse, 34, 339-345.

Dereboy, C., Demirkapi, E.S., Sakiroglu, M. and Ozturk, C.S. (2018). The relationship between childhood traumas, identity development, difficulties in emotion regulation and psychopathology. Turk Psikiyatri Derg, 29, 269278.

Erdogdu, M.Y. (2006). The relationship between parents'and teachers'attitudes and learned helplessness levels of children. Turk J Child Adolesc Ment Health, 13, 98-105.

Erkman, F. and Rohner, R.P. (2006). Youths' perceptions of corporal punishment, parental acceptance, and psychological adjustment in a Turkish metropolis. Cross-Cultural Research, 40, 250-267.

Fitzgerald, M. and Gallus, K. (2020). Emotional support as a mechanism linking childhood maltreatment and adult's depressive and social anxiety symptoms. Child Abuse Negl, 108, 104645.

Gewirtz, A., Forgatch, M. and Wieling, E. (2008). Parenting practices as potential mechanisms for child adjustment following mass trauma. J Marital Fam Ther, 34, 177-192. 
Golge, Z.B. (2005). Psychological problems occuring after sexual trauma. Noro Psikiyatr Ars, 42, 19-28.

Guloglu, B., Karairmak, O. and Emiral, E. (2016). The role of spirituality and forgiveness in childhood trauma. Anadolu Psikiyatri Derg, 17, 309-316.

Herman, J. (1992). Trauma and recovery. New York: Basic Books.

Jaffee, S.R. and Price, T.S. (2007). Gene-environment correlations: A review of the evidence and implications for prevention of mental illness. Mol Psychiatry, 12, 432-442.

Kara, B., Bicer, U. and Gokalp, A.S. (2004). Child abuse. Çocuk sağlığı ve Hastalıkları Dergisi, 47, 140-151.

Karos, K., Niederstrasser, N., Abidi, L., Bernstein, D.P. and Bader, K. (2014). Factor structure, reliability, and known groups validity of the German version of the Childhood Trauma Questionnaire (Short-form) in Swiss patients and nonpatients. J Child Sex Abu, 23, 418-430.

Miller-Graff, L.E., Scheid, C.R., Guzmán, D.B. and Grein, K. (2020). Caregiver and family factors promoting child resilience in at-risk families living in Lima, Peru. Child Abuse Negl, 108, 104639.

Moeller, F.G., Barrat, E.S., Dougherty, D.M., Schmitz, J.M. and Swann, A.C. (2001). Psychiatric aspects of impulsivity. Am J Psychiatry, 158, 1783-1793.

Morrow, J.A., Clayman, S. and McDonagh, B. (2012). In their own voices: Trauma survivors' experiences in overcoming childhooh trauma. Retrieved on March 01, $2021 \quad$ from https://journals.sagepub.com/doi/full/10.1177/2158244012440002.

Narvaez, J.C., Magalhães, P.V., Trindade, E.K., Vieira, D.C., Kauer-Sant'anna, M., Gama, C.S. and Kapczinski F. (2012). Childhood trauma, impulsivity, and executive functioning in crack cocaine users. Compr Psychiatry, 53, 238-244.

Patton, J.H., Stanford, M.S. and Barratt, E.S. (1995). Factor structure of the Barratt impulsiveness scale. J Clin Psychol, 51, 768-774.

Pereda, N., Guilera, G., Forns, M. and Gomez-Benito, J. (2009). The international epidemiology of child sexuel abuse: A continuation of Finkelhor (1994). Child Abuse Negl, 33, 331-342.

Roy, A. (2005). Childhood trauma and impulsivity. Possible relevance to suicidal behavior. Archives of Suicide Researc, 9, 147-151.

Ruggiero, J., Bernstein, D. and Handelsman L. (1999). Traumatic stress in childhood and later personality disorders: A retrospective study of male patients with substance dependence. Psychiatric Annals, 29, 713-721. 
Runyan, K.M., May-Chahal, C. and Hassan, F.(2002). Child abuse and neglect by parents and other caregivers. E.G. Krug, L.L. Dahlberg, J.A. Mercy, A.B. Zwi and R. Lozano (Rev.), In World report on violence and health (p.57-86). Geneva: World Health Organization.

Sar, V., Ozturk, P.E. and Ikikardes, E. (2012). Validity and reliability of the Turkish version of childhood trauma questionnaire. Turkiye Klinikleri J Med Sci, 32, 1054-1063.

Sekaran, V.C., Kamath, V.G., Ashok, L., Kamath, A., Hedge, A.P. and Devaramane, V. (2020). Parenting attitudes and dimensions as predictors of adolescent behavioural problems in the Indian context: A community-based study. Asian J Psychiatr, 50, 101941.

Sen, M. (2019). Examination the relationship between childhood trauma and tmpulsivity in individuals with and without psychological support. (Unpublished master's thesis). Maltepe University Social Sciences Institute, Istanbul.

Shipman, K.L., Schneider, R., Fitzgerald, M.M., Sims, C., Swisher, L. and Edwards, A. (2007). Maternal emotion socialization in maltreating and non-maltreating families: Implications for children's emotion regulation. Social Development, 16, 268-285.

Sofuoglu, Z., Oral, R., Aydin, F., Cankardes, S., Kandemirci, B., Koc, F., and Aksit, S. (2014). Epidemiological study of negative childhood experiences in three provinces of Turkey. Turk Ped Ars, 49, 47-56.

Steinberg, L., Lamborn, S.D., Darling, N., Mounts, N.S. and Dornbusch, S.M. (1994) Over-time changes in adjustment and competence among adolescents from authoritative, authoritarian, indulgent, and neglectful families. Child Dev, 65, 754-770.

Sumer, N. and Gungor, D. (1999). The impact of perceived parenting styles on attachment styles, self-evaluations and close relationships. Turk Psikoloji Derg, 14, 35-58.

Tamam, L., Gulec, H. and Karatas, G. (2013). Short form of Barratt impulsiveness scale (BIS-11-SF) Turkish adaptation study. Noro Psikiyatr Ars, 50, 130134.

Thai, T.T., Cao, P.L.T., Kim, L.X., Tran, D.P., Bui, M.B. and Bui, H.H.T. (2020). The effect of adverse childhood experiences on depression, psychological distress and suicidal thought in Vietnamese adolescents: Findings from multiple cross-sectional studies. Asian J Psychiatr, 53, 102134. 
UNICEF Turkey. Child abuse and domestic violence research in Turkey. https://www.unicef.org/turkey/media/5221/file/\%20T\%C3\%9CRK\%C4\%B0YE'DE\%20\%C3\%87OCUK\% 20\%C4\%B0ST\%C4\%BOSMARI\%20VE\%20A\%C4\%BOLE\% $20 \%$ C4\%B0 \%C3\%87\%C $\%$ B0\%20\%C5\%9E\%C4\%B0DDET\%20ARA\%C5\%9ETIR MASI\%20-\%20\%C3\%96zet\%20Raporu\%202010.pdf. Data of access, 28 September 2020

Yagci, I., Avci, S., Tasdelen, Y. and Kivrak, Y. (2018). Type D personality, childhood traumas, depression, anxiety and impulsivity in individuals attempting suicide. Anadolu Psikiyatri Derg, 19, 551-558.

Yilmaz, O., Ates, M.A., Semiz, U.B., Tutuncu, R., Bez, Y., Algul, A. and Cetin M. (2016). Childhood traumas in patients with bipolar disorder: Association with alexithymia and dissociative experiences. Anadolu Psikiyatri Derg, 17, 188-195.

Yoyen, E.G. (2017). Childhood trauma and self-respect. International Journal of Social Sciences and Education Research, 3, 267-282.

Zolotor, A.J., Runyan, D.K., Dunne, M.P., Jain, D., Péturs, H.R., Ramirez, C., and Isaeva O. (2009). ISPCAN Child Abuse Screening Tool Children's Version (ICAST-C): Instrument development and multi-national pilot testing. Child Abuse Negl, 33, 833-841.

\section{Kaynakça Bilgisi / Citation Information}

Harmancı, H., Akdeniz, S., Gültekin Ahçı, Z. and Dalmış, İ. (2021). Childhood traumas and impulsivity: The mediating role of parental attitudes. OPUS- International Journal of Society Research, 18(Eğitim Bilimleri Özel Sayıs1), 4046-4062. DOI: 10.26466/opus.904996. 